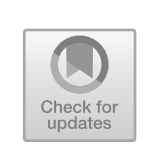

\title{
2
}

\section{Values-Reviewing the Construct and Drawing Implications for Values Work in Organisation and Leadership}

\author{
Harald Askeland
}

\section{Introduction}

Values are an inseparable part of organisational institutionalism and are at the core of the definition in many sub-streams of institutional theory. As ideas of the desirable or appropriate, values have bearing on meaning, what ought to be and choice of appropriate action. Values link to the very essence of institutions, their distinct character or identity, the logics influencing them and work done to create, maintain and change them. Values work in organisations shapes the purpose of organisations and the direction of efforts and composes criteria for the valuation of organisational practices. Increasingly embedded in multiple institutional environments or operating at institutional intersections, organisations experience pressures regarding core values, structures and processes. In this context, we argue that understanding values and abilities to perform values work

H. Askeland ( $\square)$

VID Specialized University, Oslo, Norway

e-mail: harald.askeland@vid.no 
is of importance for institutional development and institutional leadership. Supporting the aim of exploring values work, this chapter takes a closer look at the values construct itself.

While considered a dormant concept or under-developed issue for some time (Chen, Lune, \& Queen, 2013; Hitlin \& Piliavin, 2004), this book argues there is a resurgence of interest in the construct of values. This holds true in public policy discourses and in research within organisational institutionalism and leadership. Inherent in institutional arrangement, values are core constructs of normative structures and thus taken for granted. At the same time, precise prescriptions of action are not necessarily given. Being both individual and shared by collectives, values might form the base for either consensus or competing orientations among actors and interest groups.

The values construct has an enduring trajectory in academic writing on organisations and leadership (Bednarek-Gilland, 2016; Deth \& Scarbrough, 1995; Meglino \& Ravlin, 1998; Spates, 1983) but has also a natural part of everyday language, public debate and policy. The term captures increasing interest within central perspectives of institutional theory, such as institutional logics (Friedland \& Alford, 1991; Krücken, Meyer, \& Walgenbach, 2017), institutional work (Lawrence, Leca, \& Zilber, 2013), values work (Aadland et al., 2006; Askeland, 2014; Gehman, Trevino, \& Garud, 2013; Vaccaro \& Palazzo, 2014) and identity work (Albert \& Whetten, 1985; Schmid, 2013; Watson, 2008). Also within the field of research on managers or leaders, we see a resurgence of an interest in values. Values is an important concept in perspectives such as managing and institutional leadership (Cameron, Quinn, DeGraff, \& Thakor, 2006; Kraatz \& Flores, 2015; Mintzberg, 2009; Raffaelli \& Glynn, 2015), public administration (de Vries \& Kim, 2011; Jørgensen, Vrangbæk, \& Sørensen, 2013; Moore, 1995) and nonprofit management (Aadland \& Skjørshammer, 2012; Askeland, 2011, 2015; Jeavons, 1992; Knutsen, 2012). Yet, in spite of this renewed interest, the term itself remains somewhat ambiguous and taken for granted. This ambiguity is argued to be inherent in values, allowing for differing interpretations by actors while at the same time creating a sense of unity (Askeland, Espedal, \& Sirris, 2019). 
This chapter outlines the trajectory of values, particularly within streams of organisational institutionalism, in order to analyse its application to values work in organisation and leadership. Conveying a frame for discussing values work in this book requires clarification of how we conceptualise the concept values. While economists relate value to objects, which differs in value due to the strength of preference of actors or consumers, I will position it in line with contributions that underscore values' relation to valuation emanating from meaning, concern, normative agreements and what is considered desirable (Askeland \& Aadland, 2017; Bednarek-Gilland, 2016; Kluckhohn, 1951; Spates, 1983). The latter makes the connection of individuals and collectives a crucial issue.

\section{Basic Distinctions and Trajectory of the Values' Concept}

Basic distinctions of the term values stem from differing paradigms and often represent single perspectives. Such basic positions relate to various positions of philosophy of science in the social sciences (Hollis, 2002; Kemmis, 2011), and I argue it can be applied to separate contributions linking values to organisation and leadership. Two key dimensions, each one claiming opposing views, have consequences for the study and explanation of values. The first dimension regards the distinction between objective and subjective, while the other regards structure versus agency. The first distinction affects viewing values either in a factual or interpretive way, while the other affects viewing values as either individual properties or collectively articulated and shared.

It is possible to identify two different basic understandings of values (Aadland, 2010; Bednarek-Gilland, 2016), often referred to as the distinction between 'facts and ideals'. This distinction draws on Simon, who distinguishes between factual and ethical (ideational) aspects of decisions in organisations (Simon, 1957, pp. 55-57). Research on values consequently often uses differing strategies and methodologies.

The major tradition conceptualises values as inherent qualities identified and explored as objectively existing phenomena of social life (Meglino \& Ravlin, 1998). Even if values are conceptualised partly as 
beliefs (Rokeach, 1973; Schwartz, 1994), research has concentrated on establishing measurement instruments to map existing patterns of values among individual actors and between national cultures. Major international surveys on values, which find different cultural and social patterns in different countries' values, apply this perception of values and ascribe them structural properties that influence behaviour (Inglehart, 1990; Schwartz, 2006). One of the most influential contributions to values research, and much cited in the scholarly literature, defines values as 'an enduring belief that a specific mode of conduct or end-state of existence is personally or socially preferable to an opposite or converse mode of conduct or end-state of existence' (Rokeach, 1973, p. 5). The values described in surveys are short forms of people's action flexibilities. Such a perception, applied to values work, argues leaders should identify desirable organisational values and launch measures to ensure the implementation of those values (Lencioni, 2002). This perception is indebted to a somewhat positivist view of science and characterised as objectivist values (Bednarek-Gilland, 2016, p. 2), concerning studying values for practice. Consequently much research in this tradition, as represented by Rokeach and Schwartz, implicitly addresses values in an individualistic manner (Chanut, Chomienne, \& Desmarais, 2015, p. 221). Questionnaires address individual respondents, and the collective or shared aspect of values is portrayed as an aggregated accumulation of individuals to the group level.

Another approach regards values as phenomena constructed and added to common sense in the social space, catching attention and affecting practice for a time and later replaced by new issues (Aadland, 2010; Bednarek-Gilland, 2016; Deth \& Scarbrough, 1995). An important idea put forth by Van Deth and Scarbrough contributes particularly to a collective grounding of values: 'Values could be seen as conceptions of the desirable, which are not directly observable, but are evident in moral discourse and patterns of attitudes forming value orientations with relevance to action' (Deth \& Scarbrough, 1995). Values are, in other words, linguistic constructions that express assigned importance. They inherently rely on arguments such as 'ought', 'preferable' and 'good', having moral or ethical implications not reducible to factual terms (Simon, 1957, p. 56). Values, therefore, cannot be studied directly; they 
function more like projections and interpretations by a person of what is a good or wrong act or thing (Askeland \& Aadland, 2017, p. 27; Gehman et al., 2013). Values develop through dialogue and interpretation in specific contexts. Bednarek-Gilland (2016) underscores this, arguing values can change due to experiential learning through facing issues or situations related to what concerns actors. Such concern represents states of being that are 'trans-situative' and 'trans-subjective' (Bednarek-Gilland, 2016, p. 4). Various actors bring their own experiences, assessments and interests into the opinion formation process. Organisational practice is ambiguous, and the relationship between values and action cannot be proven in a closed chain of logical cause and effect (Aadland, 2010). This points at experience as central in both the inculcation and eventual transformation of values. Consequently, values tied to social collectives and/or organisations through articulation are part of common sense or a shared meaning- or norm-structure. Such an understanding, focusing on social construction, implies more use of qualitative data.

In both understandings, the concept of values closely relates to ethics and morality. Values indicate good and wrong and function both as descriptive and normative concepts. In their descriptive function, values describe actual valuation practices that characterise people in a given group or how values develop as meaningful in given contexts. In a normative function, values inform ideals and overall objectives-whether understood as timeless and universal or as relative and contextual in nature.

Furthermore, Brown and Treviño argue there exists little correlation between different theories and measures within the research on values and values in organisation and leadership (Brown \& Treviño, 2003, p. 154). A major exception, reviewed briefly later in this chapter, is the different sub-streams of institutional theory. Although used, authors seldom define values. And their effects are briefly spelled out and taken for granted. This may indicate there has been little focus on which or what kind of values authors convey or that the question of values' significance for action and interaction is a topic that garners little attention (Maierhofer, Rafferty, \& Kabanoff, 2003). Within management and leadership research, there are nevertheless some important exceptions. 
Two major streams, dating back to the late 1970s and stemming from the turn to leadership, are charismatic value-based leadership (House, 1976) and transformational leadership (Avolio \& Bass, 1995; Burns, 1978). A Scandinavian tradition conceptualises values in leadership more as a leadership philosophy, aimed at creating and sustaining a consensual base of values to guide organisational practices but with weak ties to management or leadership theory (Aadland et al., 2006; Brytting \& Trollestad, 2000; Petersen \& Lassen, 1997). These Scandinavian contributions, focusing on the collective articulation and implementation of values, come close to what is termed values work. Recent research displays renewed interest in the relationship between 'public values' and the value orientation of leaders' in public services (Chanut et al., 2015; Jørgensen, 2006; Tholen, 2011). Other contributions build on Selznick's notion of institutional leadership (Kraatz \& Flores, 2015; Raffaelli \& Glynn, 2015; Washington, Boal, \& Davis, 2008) and finally research on how values shape important processes of institutional work framed as values work (Askeland, 2014; Gehman et al., 2013; Vaccaro \& Palazzo, 2014).

\section{Values in Streams of Institutional Theory}

The concept of values, historically applied in several academic disciplines, permeates institutional theory of organisation and leadership. The term is used in such a variety of ways that a precise and unambiguous definition may seem unattainable. In the field of social science in general, central concepts have been close to the notion of values. The field's classics were already keen on rationality and cognitive or cultural patterns as explanatory factors of social life. This is especially true of Max Weber, describing comprehensive cultural changes of rationality as the basis for the development of social forms, using the term value-oriented rationality for action based on the self-conscious conviction that the action has a value inherent to itself, independent of any consequences it might or might not have (Weber, 1978). Value-rationality is contrasted by purposeful rational action, aiming at realising certain goals, while valueoriented rational action stems from compliance with policies or standards 
that are binding in themselves. However, the one who put values on the agenda for comprehensive research interest was Talcott Parsons (1951). The idea of common normative thought patterns from the classics continued in the concept of value. '[T] he most important of these normative agreements were what Parsons called values - those moral beliefs to which people appealed for the ultimate rationales for action' (Spates, 1983, p. 28). Social anthropologist Clyde Kluckhohn formulated the following use and understanding of the concept of value:

A value is a conception, implicit or explicit, distinctive of an individual or characteristic of a group, of the desirable, which influences the selection from available modes, means and ends of action. (Kluckhohn, 1951, p. 395)

This definition focuses on some important elements. First, it points to the notion that something is desirable. This implies conceiving values as normative ideals; they are mental constructs, not unbiased artefacts. Second, the definition implies that values affect the choice of available goals and options for action. Third, it distinguishes between implicit and explicit values. While the articulation and attribution of content distinguish an explicit value, implicit values lack a common conceptualisation. One last important point is Kluckhohn's emphasis on the desirable rather than desired, which positions the value concept of closer to ethics' 'should' than to psychology's 'need'. In this understanding of values, there are important elements that only affect the relationship between values and action (Deth \& Scarbrough, 1995, pp. 31-36). As ideas of the desirable, values can mobilise the notion of what should happen, acted upon or be used as a basis for valuation.

Institutional theories have risen to become a dominant sociological and organisational theory of collectives and collective action. Moreover, the concept of values constitutes an inseparable part of institutional theories. Most obviously, values are key in Selznick's conceptualisation of institutions and institutional leadership. In contrast to organisations, understood as administrative and technical systems, he emphasises the institution as being a kind of informal 'social constitution' shaped by 'natural social processes' and 'adaptive changes', leading to a process of 
institutionalisation in which it is 'infused with value beyond the technical requirements of the task at hand' (Selznick, 1957/1984, p. 17). Distinguishing administration from leadership, Selznick portrays the institutional leader as 'primarily an expert in the promotion and protection of values' (Selznick, 1957/1984, p. 17).

Later contributions also continue to include values when defining the term institution: 'We see institutions as cultural rules giving collective meaning and value to particular entities and activities, integrating them into the larger schemes' (Meyer \& Boli, 1987, p. 13). In most definitions, values is implicitly embedded in terminology such as 'normative systems', 'beliefs' and 'cognitive understandings': '(...) we understand the term to refer to more-or-less taken-for-granted repetitive social behavior that is underpinned by normative systems and cognitive understandings that give meaning to social exchange and thus enable self-reproducing social order' (Greenwood, Oliver, Sahlin, \& Suddaby, 2008, p. 5).

According to Scott, this is particularly true for one cluster of theories, the normative theories, attending to the ways in which values, norms and commitments generated in interaction shape, undermine and augment formal and official regimes (Scott, 2004, p. 410). Their importance lies in introducing prescriptive, evaluative and obligatory dimensions into social life. As a response, individual or collective actors determine the nature of the situation, reflect on the nature of their own identity and act accordingly. Values might also be important from the culturalcognitive perspective, as such view rests on more 'deeply set beliefs and assumptions' (Scott, 2005, p. 16). Therefore, an early key contribution of institutional theory has been accounts of the processes by which behaviour is governed by institutions or by institutionalised, taken-forgranted assumptions (Lawrence \& Suddaby, 2006, p. 215). Across the contributions, authors have accepted the notion that values affect organisations and that organisations adopt structures and practices in order to gain legitimacy (Greenwood et al., 2008, p. 7).

The further development of institutional theory nuanced the overall notion of adaption, thus challenging this assumed causal argument (Scott, 2005). A first nuance was recognising the varied and conflicting nature of institutional environments, which consisted of fields with differing and plural value orientations inherent in institutional logics 
(Friedland \& Alford, 1991). ${ }^{1}$ In the subsequent development of the institutional logics perspective, values were originally maintained as part of defining logics (Thornton \& Ocasio, 2008).

Secondly, actors and their capacity to exercise agency and make a difference paved the way for processual approaches to examine how actors handle differing pressures or work to maintain or change institutions. Particularly in explaining change, institutional theory needed to incorporate 'the reality of purposive, interest-driven, and conflictual behavior' (DiMaggio, 1988, p. 5). Institutional work which is 'the purposive action of individuals and organisations aimed at creating, maintaining and disrupting institutions' (Lawrence \& Suddaby, 2006, p. 215) underscores an actor's perspective. Institutional work presupposes that individuals' and organisations' behaviour is framed by larger patterns of ideas and opinions about what is 'good or less good' in organisational and management practice. Values are critical in the establishment or implementation of institutionalised practice but have particular emphasis in phases where organisations maintain, for example, their normative or value-based basis (Lawrence \& Suddaby, 2006, pp. 222-230).

Of special interest, I find contributions of values work that identify and integrate the agentic efforts in temporal processes mobilising action based on or in support of values (Gehman et al., 2013; Vaccaro \& Palazzo, 2014). ${ }^{2}$ In addition, contributions addressing the particular role of leaders in infusing or promoting values in organisations are of interest (Askeland, 2014; Golant, Sillince, Harvey, \& Maclean, 2015; Kraatz \& Flores, 2015; Raffaelli \& Glynn, 2015; Washington et al., 2008).

In these contributions, values are usually not explicitly defined but instead taken for granted. One exception is the work of Gehman and colleagues (2013), which explicates a values definition but does not elaborate on it. While functionalist theory, and the Parsonian legacy, had lost strength, theoretical inspiration for institutional theories came from classical theorists such as Durkheim and Weber (Durkheim, 2001; Weber, 1978) as well as Berger and Luckman, applying the notion of institutionalisation in their sociology of knowledge (Berger \& Luckmann, 1967).

\footnotetext{
${ }^{1}$ For a further elaboration on the logics perspective, see Sirris's chapter in this book.

${ }^{2}$ For a review on the values work literature, see Espedals contribution in this volume.
} 
Scott contends that the normative perspective in institutional theory borrows from earlier, normatively oriented sociologists such as Parsons and Selznick (Parsons, 1935, 1960; Scott, 2005; Selznick, 1949, 1957/1984).

Following Spates, it seems reasonable that this taken-for-granted use of the concept of values relies heavily on a Parsonian understanding of values. Spates argues that the basic idea that values were a controlling factor in social life, which permeated American sociology, is an enduring Parsonian legacy (Spates, 1983, p. 30). As argued in an earlier section, Kluchhohn's definition of values is one of the most widely used, implying that values become the instigator of behaviour 'within' the individual through socialisation. As such, they convey legitimacy when observed; they order social life by shaping behavioural orientation by being institutionalised and taking on rule-likeness. All these components, emanating from within the Parsonian values theory (Parsons, 1951; Spates, 1983, p. 31), are traceable in major contributions of institutional theory although supplemented by refinement and the incorporation of re-constructed theoretical considerations. Important ideas contradicting these basic assumptions relate to issues of institutional pluralism and conflicting logics, agency and the processes accompanying the creation, maintenance and change of institutions and institutionalised practices.

Values are part of the core construction of or definition in the following four important contemporary streams of institutional theory of particular interest in this book: institutional leadership, institutional identity, institutional logics and institutional (values) work.

\section{Rounding Out the Concept of Values}

The concept of values, as it originated in sociology, permeates the institutional theory of organisation and leadership. Caused by variety of definitions, a rounding out of the term seems preferable over a precise and unambiguous definition. In the social sciences, the term has been used in social economics, sociology, social psychology, political science and social anthropology but with only some connection or similarity in 
how it has been used in the various academic fields (Graeber, 2001; Hitlin \& Piliavin, 2004). While values theory has enjoyed some development regarding its explication and measurement through value surveys (House, Quigley, \& de Luque, 2010; Meglino \& Ravlin, 1998; Rokeach, 1973; Schwartz, 2006), it seems to be an under-specified yet frequently used and taken-for-granted term in streams of institutional theory (Friedland, 2017). Based on earlier contributions, I suggest a 'rounding out' of the values term combining prior (Kluckhohn, 1951; Rokeach, 1973; Schwartz, 1994) and more recent developments (Askeland \& Aadland, 2017; Bednarek-Gilland, 2016; Gehman et al., 2013).

For such a 'rounding out' regarding values, there are important elements affecting the relationship between values and action (Deth \& Scarbrough, 1995, pp. 31-36). As ideas of the desirable, values can mobilise the notion of what ought to happen or be the basis for valuation. At the same time, values do not directly prescribe any specific action choices but rather form principles upon which to assess or valuate action. Van Deth and Scarbrough assume that patterns of attitudes constitute value orientations, which in turn indirectly manifest themselves in actions. While held by individuals, values become social through articulation and form a part of common sense or serve as underlying normative structures. ${ }^{3}$ As such, they can be shared by [members of] an organised collective. Values also relate to the interests of actors or groups and are also situated in differing contexts, which implies they are not necessarily organised hierarchically but rather related in 'clusters' of neighbouring values (Stackman, Pinder, \& Connor, 2000). These clusters may form orientations, even within the same organisation, where different groups place more or less importance on professional, administrative and economic values. Thus, it becomes likely that there might be tension and conflict among the various clusters of values constituting competition or dilemmas needing to be resolved (Quinn \& Rohrbaugh, 1983; Selznick, 1957).

As a working definition for studying values work in organisations and leadership, I propose to conceive of values as:

\footnotetext{
${ }^{3}$ For a more thorough discussion on differing forms of values at the collective or organizational level, see Bourne and Jenkins's elaborate categorisation (Bourne \& Jenkins, 2013).
} 
Values are individual and collective conceptions of desirable transsituational behaviours, objectives and ideals, serving to guide or valuate practice.

Implicit in this definition is that values (1) are either explicitly or implicitly contextual (spatial and temporally situated); (2) serve to mobilise for and direct action; (3) are not observable but manifested in or as the valuation of practice; (4) are acquired through socialisation into group values yet changeable through experiential learning; (5) are constituted, maintained and changed in dialectical interaction between the individual and his or her social collective and (6) even when shared they are ambiguous and open for interpretation.

Leaders contribute by focusing on values and ethical considerations to 'frame' value standards for the organisation and its behaviour as well as drawing boundaries for types of behaviour deemed unacceptable. This has implications internally in the organisation as well as for its legitimacy in relation to the external environment. Increasingly organisations and leaders find themselves in plural institutional contexts, representing conflicting or co-existing institutional logics. While institutional theory has traditionally emphasised external pressure leading to organisational adaption or differing adaptive or coping strategies, the last two decades have produced contributions arguing for bringing both society (Friedland \& Alford, 1991), the agentic actor (Battilana, 2004; Kraatz, 2009) and work back in (Barley \& Kunda, 2001). These streams of research and theorising developed into differentiated perspectives, and few studies connect these perspectives. While not aiming at resolving this differentiation, I argue that values entail a concept central to all of these strands of research interest and constitute a venue for examining commonalities and points of departure for bridging efforts.

\section{Implications for Values Work in Organisation and Leadership}

Although sub-streams of institutional theory often employ the term values in core definitions, hardly ever is the term elaborated or clarified. 
At the same time, many basic assumptions of Parsonian theory underpin the functions attributed to values, either taking values for granted or omitting the values term, substituting it with terms like 'normative expectations', 'beliefs' and 'cognitive structures' (Friedland, 2017). Institutional logics, which is of interest for contributions of the book, rarely define the values term in recent work although it was a central concept in the originating works (Friedland, 2017; Friedland \& Alford, 1991). Important exceptions are the resurgence of interest in institutional leadership (Kraatz \& Flores, 2015; Washington et al., 2008) and values work (Gehman et al., 2013).

Such exploration should more generally attend to issues such as spanning the micro-macro divide, the importance of context, temporal or processual aspects, organisational identity and finally the intentionality or agentic aspect of values work.

Finally, the chapter elaborates on how a renewed conceptualisation of values (Askeland \& Aadland, 2017; Bednarek-Gilland, 2016) might inform further research on values work in organisation and leadership studies. In explicating the role of values, their situatedness in contexts marked by pluralistic institutional environments (Kraatz \& Block, 2017) become critical. Studying organisations at intersections of differing fields necessitates a conscious explication of how values relate to both individual organisations and their embeddedness in particular fields. In particular, values are key to exploring how organisations come to hold specific values, either aligning with plural external and internal demands or developing distinct values, giving character to the organisation. While institutional leadership traditionally is closely related to maintenance processes, closer attention must be paid to the ongoing adaption and re-articulation of values as institutional contexts either change or evolve into institutional pluralism. I suggest special attention should be given to how change or re-alignment occurs through experiential learning as leading actors facilitate organisational processes and dialectical interaction to promote new, shared understandings of values in organisations. The seemingly ambiguous nature of values might enable intentional efforts of such articulation or framing. In allowing sharing yet individually interpreting values, values work might promote unified diversity, encouraging 
ongoing and recurring exploration of meaning and practices and link continuity with contextually situated adaptive change.

Several of the remaining chapters of this book undertake such efforts, expanding our understanding of 'who' performs values work and 'how' processes evolve temporally. This might shed light on the ongoing reexplication of institutional leadership but also contribute to bridging the inter-relatedness of the institutional logics and institutional work perspectives.

\section{References}

Aadland, E. (2010). Values in professional practice: Towards a critical reflective methodology. Journal of Business Ethics, 97(3), 461-472.

Aadland, E., Askeland, H., Flatebø, E., Haugen, H., Kaasa, A., \& Stapnes, L. M. (2006). Verdibasert ledelse i praksis [Values-based leadership in practice]. Oslo: HSH.

Aadland, E., \& Skjørshammer, M. (2012). From God to good? Faith-based institutions in the secular society. Journal of Management, Spirituality \& Religion, 9(1), 1-19.

Albert, S., \& Whetten, D. A. (1985). Organizational identity. Research in Organizational Behavior, 7, 263-295.

Askeland, H. (2011). What do diaconal hospital managers really do? Management at Diakonhjemmet Hospital: Context, intention and practice. Diaconia: Journal for the Study of Christian Social Practice, 2(2), 145-169.

Askeland, H. (2014). Leaders should be the carriers of institutional values: An account of how leaders contribute to the value-base of diaconal institutions. Diaconia, 5(2), 149-177.

Askeland, H. (2015). Managerial practice in faith-based welfare organizations. Nordic Journal of Religion and Society, 28(1), 37-58.

Askeland, H., \& Aadland, E. (2017). Hva er verdier, og hva tjener de til? [What are values and their purpose?]. In E. Aadland \& H. Askeland (Eds.), Verdibevisst ledelse [Values-conscious leadership]. Oslo: Cappelen Damm Akademisk.

Askeland, H., Espedal, G., \& Sirris, S. (2019). Values as vessels of religion? Role of values in everyday work at faith-based organizations. Diaconia. Journal for the Study of Christian Social Practice, 10(1), 27-49. 
Avolio, B. J., \& Bass, B. M. (1995). Individual consideration viewed at multiple levels of analysis: A multi-level framework for examining the diffusion of transformational leadership. The Leadership Quarterly, 6(2), 199-218.

Barley, S. R., \& Kunda, G. (2001). Bringing work back in. Organization Science, 12(1), 76-95.

Battilana, J. (2004). Foundations for a theory of institutional entrepreneurship: Solving the paradox of embedded agency. Paper presented at the Academy of Management Annual Meeting, New Orleans, LA.

Bednarek-Gilland, A. (2016). Researching values with qualitative methods: Empathy, moral boundaries and the politics of research: New York: Routhledge.

Berger, P. L., \& Luckmann, T. (1967). The social construction of reality: A treatise in the sociology of knowledge (Anchor Books ed.). Garden City, NY: Doubleday.

Bourne, H., \& Jenkins, M. (2013). Organizational values: A dynamic perspective. Organization Studies, 34(4), 495-514.

Brown, M. E., \& Treviño, L. K. (2003). Is value-based leadership ethical leadership? In S. W. Gilliand, D. Steiner, \& D. Skarlicki (Eds.), Emerging perspectives on values in organizations. Greenwich: Information Age Publishing. Brytting, T., \& Trollestad, C. (2000). Managerial thinking on value-based management. International Journal of Value-Based Management, 13(1), 55-77.

Burns, J. (1978). Leadership. New York: Harper \& Row.

Cameron, K. S., Quinn, R. E., DeGraff, J., \& Thakor, A. V. (2006). Competing values leadership: Creating values in organizations. Cheltenham: Edward Elgar.

Chanut, V., Chomienne, H., \& Desmarais, C. (2015). Value practices and public management. International Review of Administrative Sciences, 81(2), 219-226.

Chen, K. K., Lune, H., \& Queen, E. L. (2013). How values shape and are shaped by nonprofit and voluntary organizations: The current state of the field. Nonprofit and Voluntary Sector Quarterly, 42(5), 856-885.

Deth, J. W. V., \& Scarbrough, E. (1995). The concept of values. In J. W. V. Deth \& E. Scarbrough (Eds.), The impact of values (pp. 21-47). Oxford: Oxford University Press.

de Vries, M., \& Kim, P. S. (2011). Value and virtue in public administration. London: Palgrave Macmillan.

DiMaggio, P. J. (1988). Interest and agency in institutional theory. Institutional Patterns and Organizations: Culture and Environment, 1, 3-22.

Durkheim, É. (2001). The elementary forms of religious life. Oxford: Oxford University Press. 
Friedland, R. (2017). The value of institutional logics. In G. Krücken, C. Mazza, R. Meyer, \& P. Walgenbach (Eds.), New themes in institutional analysis: Topics and issues from European research (p. 12). Cheltenham: Edward Elgar.

Friedland, R., \& Alford, R. R. (1991). Bringing society back in: Symbols, practices, and institutional contradictions. In W. W. Powell \& P. J. DiMaggio (Eds.), The new institutionalism in organizational analysis (p. 478). Chicago: University of Chicago Press.

Gehman, J., Trevino, L. K., \& Garud, R. (2013). Values work: A process study of the emergence and performance of organizational values practices. Academy of Management Journal, 56(1), 84-112.

Golant, B. D., Sillince, J. A., Harvey, C., \& Maclean, M. (2015). Rhetoric of stability and change: The organizational identity work of institutional leadership. Human Relations, 68(4), 607-631.

Graeber, D. (2001). Toward an anthropological theory of value: The false coin of our own dreams. New York: Palgrave.

Greenwood, R., Oliver, C., Sahlin, K., \& Suddaby, R. (2008). Introduction. In R. Greenwood, C. Oliver, R. Suddaby, \& K. Sahlin (Eds.), The SAGE handbook of organizational institutionalism. Thousand Oaks, CA: Sage.

Hitlin, S., \& Piliavin, J. A. (2004). Values: Reviving a dormant concept. Annual Review of Sociology, 30, 359-393.

Hollis, M. (2002). The philosophy of social science: An introduction (Rev. and updated ed.). Cambridge: Cambridge University Press.

House, R. J. (1976). A 1976 Theory of charismatic leadership. Paper presented at the Southern Illinois University Fourth Biennial Leadership Symposium, Carbondale, IL.

House, R. J., Quigley, N. R., \& de Luque, M. S. (2010). Insights from Project GLOBE: Extending global advertising research through a contemporary framework. International Journal of Advertising, 29(1), 111-139.

Inglehart, R. (1990). Culture shift in advanced industrial society. Princeton, NJ: Princeton University Press.

Jeavons, T. M. (1992). When the management is the message: Relating values to management practice in nonprofit organizations. Nonprofit Management \& Leadership, 2(4), 403-417.

Jørgensen, T. B. (2006). Public values, their nature, stability and change: The case of Denmark. Public Administration Quarterly, 30(3), 365-398.

Jørgensen, T. B., Vrangbæk, K., \& Sørensen, D.-L. (2013). The historical development of values in Danish administrative reform. Paper presented at 
the 11th Public Management Research Association Conference, La Follette School Public Affairs, University of Wisconsin.

Kemmis, S. (2011). What is professional practice? Recognising and respecting diversity in understandings of practice. In C. Kanes (Ed.), Elaborating professionalism: Studies in practice and theory. Dordrecht, London, and Boston: Springer Science.

Kluckhohn, C. (1951). Values and value-orientations in the theory of action: An exploration in definition and classification. In T. Parsons \& E. Shils (Eds.), Toward a general theory of action. Cambridge, MA: Harvard University Press.

Knutsen, V. L. (2012). Value as self-sustaining mechanism: Why some nonprofit organizations are different from and similar to private and public organizations. Nonprofit and Voluntary Sector Quarterly, 42(5), 985-1005.

Kraatz, M. S. (2009). Leadership as institutional work: A bridge to the other side. In T. B. Lawrence, R. Suddaby, \& B. Leca (Eds.), Institutional work: Actors and agency in institutional studies of organizations (pp. 59-91). Cambridge: Cambridge University Press.

Kraatz, M. S., \& Block, E. S. (2017). Institutional pluralism revisited. In R. Greenwood, C. Oliver, T. B. Lawrence, \& R. E. Meyer (Eds.), The SAGE handbook of organizational institutionalism (pp. 532-557). Los Angeles: Sage.

Kraatz, M. S., \& Flores, R. (2015). Reinfusing values. Institutions and ideals: Philip Selznick's legacy for organizational studies, 44, 353À381.

Krücken, G., Meyer, R., \& Walgenbach, P. (2017). New themes in institutional analysis: Topics and issues from European research. In G. Krücken, C. Mazza, R. Meyer, \& P. Walgenbach (Eds.), New themes in institutional analysis: Topics and issues from European research (pp. 1-11). Cheltenham, UK: Edward Elgar.

Lawrence, T., \& Suddaby, R. (2006). Institutions and institutional work. In S. R. Clegg, C. Hardy, T. Lawrence, \& W. R. Nord (Eds.), The SAGE handbook of organization studies (2nd ed., pp. 215-254). Thousand Oaks, CA: Sage.

Lawrence, T. B., Leca, B., \& Zilber, T. B. (2013). Institutional work: Current research, new directions and overlooked issues. Organization Studies, 34(8), 1023-1033.

Lencioni, P. M. (2002). Make your values mean something. Harvard Business Review, 80(7), 113-117.

Maierhofer, N. I., Rafferty, A. E., \& Kabanoff, B. (2003). When and why are values important in organizations. In S. W. Gilliland, D. D. Steiner, 
\& D. P. Skarlicki (Eds.), Emerging perspectives on values in organizations (pp. 3-32). Greenwich, CT: Information Age Publishing.

Meglino, B. M., \& Ravlin, E. C. (1998). Individual values in organizations: Concepts, controversies, and research. Journal of Management, 24(3), 351-389.

Meyer, J. W., \& Boli, J. (1987). Ontology and rationalization in the Western cultural account. In George M. Thomas et al., Institutional Structure: Constituting State, Society and the Individual, 12-37.

Mintzberg, H. (2009). Managing. San Fransisco, CA: Berrett-Koehler.

Moore, M. H. (1995). Creating public value: Strategic management in government. Cambridge, MA: Harvard University Press.

Parsons, T. (1935). The place of ultimate values in sociological theory. International Journal of Ethics, 45(3), 282-316.

Parsons, T. (1951). The social system (1st ed.). New York: The Free Press of Glencoe.

Parsons, T. (1960). Structure and process in modern society. Glencoe, IL: Free Press.

Petersen, V. C., \& Lassen, M. S. (1997). Verdibaseret ledelse-et alternativ til styring, regulering og kontrol? [Values-based leadership-Alternative to governing, regulation and control?]. København: Dansk Industri.

Quinn, R. E., \& Rohrbaugh, J. (1983). A spatial model of effectiveness criteria: Towards a competing values approach to organizational analysis. Management Science, 29(3), 363-377.

Raffaelli, R., \& Glynn, A. (2015). What's so institutional about leadership? Leadership mechanisms of value infusion. In M. S. Kraatz (Ed.), Institutions and ideals: Philip Selznick's legacy for organizational studies (Vol. 44). Bingley, UK: Emerald.

Rokeach, M. (1973). The nature of human values. New York: Free Press.

Schmid, H. (2013). Nonprofit human services: Between identity blurring and adaptation to changing environments. Administration in Social Work, 37(3), 242-256.

Schwartz, S. H. (1994). Are there universal aspects in the structure and contents of human values? Journal of Social Issues, 50(4), 19-45.

Schwartz, S. H. (2006). A theory of cultural value orientations: Explication and applications. Comparative Sociology, 5(2/3), 137-182.

Scott, W. R. (2004). Institutional theory. Encyclopedia of Social Theory, 11, 408-414.

Scott, W. R. (2005). Institutional theory: Contributing to a theoretical research program. Great Minds in Management: The Process of Theory Development, 37, 460-485. 
Selznick, P. (1949). TVA and the grass roots: A study in the sociology of formal organization. Berkeley: University of California Press.

Selznick, P. (1957/1984). Leadership in administration: A sociological interpretation. Berkeley: University of California Press.

Simon, H. A. (1957). Administrative behavior: A study of decision-making processes in administrative organization (2nd ed.). New York: Simon \& Schuster and Free Press.

Spates, J. L. (1983). The sociology of values. Annual Review of Sociology, 9(1), 27-49.

Stackman, R. W., Pinder, C. C., \& Connor, P. E. (2000). Values lost: Redirecting research on values in the workplace. Handbook of organizational culture and climate (pp. 37-54). Thousand Oaks, CA: Sage.

Tholen, B. (2011). Public virtue approaches. In Value and virtue in public administration (pp. 33-46). London: Palgrave Macmillan and Springer.

Thornton, P. H., \& Ocasio, W. (2008). Institutional logics. In R. Greenwood, C. Oliver, R. Suddaby, \& K. Sahlin (Eds.), The SAGE handbook of organizational institutionalism (Vol. 840, pp. 99-128). London: Sage.

Vaccaro, A., \& Palazzo, G. (2014). Values against violence: Institutional change in societies dominated by organized crime. Academy of Management Journal, 58(4), 1075-1101.

Washington, M., Boal, K. B., \& Davis, J. N. (2008). Institutional leadership: Past, present, and future. In R. Greenwood, R. Suddaby, C. Oliver, \& K. Sahlin (Eds.), Handbook of organization institutionalism (pp. 721-736). London: Sage.

Watson, T. J. (2008). Managing identity: Identity work, personal predicaments and structural circumstances. Organization, 15(1), 121-143.

Weber, M. (1978). Economy and society: An outline of interpretive sociology. Berkeley, CA.: University of California Press. 
Open Access This chapter is licensed under the terms of the Creative Commons Attribution 4.0 International License (http://creativecommons.org/ licenses/by/4.0/), which permits use, sharing, adaptation, distribution and reproduction in any medium or format, as long as you give appropriate credit to the original author(s) and the source, provide a link to the Creative Commons license and indicate if changes were made.

The images or other third party material in this chapter are included in the chapter's Creative Commons license, unless indicated otherwise in a credit line to the material. If material is not included in the chapter's Creative Commons license and your intended use is not permitted by statutory regulation or exceeds the permitted use, you will need to obtain permission directly from the copyright holder.

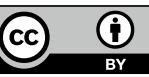

